\title{
Rumen $\mathrm{pH}, \mathrm{NH}_{3}-\mathrm{N}$ concentration and forage degradation kinetics of cows grazing temperate pastures and supplemented with different sources of grain
}

\author{
Cecilia CAJARVILLE*, Martín Aguerre, José Luis RePetTo \\ Departamento de Nutrición Animal, Facultad de Veterinaria, Universidad de la República Oriental del \\ Uruguay (UdelaR), Lasplaces 1550, Montevideo, Uruguay
}

(Received 8 November 2005 - Accepted 15 September 2006)

\begin{abstract}
The objective of this work was to evaluate the effect of punctual grain supplementations on rumen degradation of cows grazing temperate pastures, with emphasis on degradation of fibrous components and in relation to rumen $\mathrm{pH}$ and $\mathrm{NH}_{3}-\mathrm{N}$ concentrations. Two experiments were conducted with 4 cannulated cows grazing a temperate grass and legume mixture. In experiment 1 , treatments were: pasture grazed as sole feed ('pasture') and pasture supplemented with 6 $\mathrm{kg} \cdot \mathrm{day}^{-1}$ of corn/wheat $(50 / 50, \mathrm{w} / \mathrm{w})$ ('grain'). In experiment 2 , supplementation $(3.8 \mathrm{~kg})$ of wheat and corn were compared. Diurnal rumen $\mathrm{pH}$ dynamics and nylon bag degradability of dry matter (DM) and fibre fractions of the grazed pasture were measured in both experiments. Additionally, the in vitro digestibility of a collection of feedstuffs (IVTD) was assessed using rumen contents of animals of Experiment 2. Supplementation affected the average pH ('pasture': 6.54 vs. 'grain': $6.24, P<0.001)$ and the fractional degradation rate $(k d)$ of the pasture DM, which was lower when cows were supplemented $(P=0.048)$. The nature of supplemented grain did not affect rumen $\mathrm{pH}$, $\mathrm{NH}_{3}-\mathrm{N}$ concentration, DM or fibre degradation of the in situ incubated forage. However, IVTD was higher when cows consumed corn than wheat for most in vitro incubated substrates, with larger differences for more fibrous material.
\end{abstract}

rumen environment / rumen degradability / temperate pasture / wheat / corn

Résumé - Concentration en $\mathrm{NH}_{3}-\mathrm{N}$, le $\mathbf{p H}$ et les cinétiques de dégradation ruminales des fourrages chez des vaches au pâturage supplémentées avec deux types de céréales. Les effets de la supplémentation ponctuelle en céréales sur la dégradation ruminale chez des vaches pâturant des prairies tempérées ont été étudiés, en mettant l'accent sur la dégradation des fractions fibreuses en relation avec le $\mathrm{pH}$ ruminal et la concentration en $\mathrm{NH}_{3}-\mathrm{N}$. Deux essais ont été menés, utilisant 4 vaches canulées pâturant une prairie tempérée de légumineuses et de graminées. Dans le premier essai, les traitements étaient : le pâturage (aliment unique) (" fourrage ") et le pâturage supplémenté avec $6 \mathrm{~kg}$ d'un mélange de maïs et de blé $(50 / 50, \mathrm{w} / \mathrm{w})$ (“" grain ”).

\footnotetext{
*Corresponding author: nutrag@ adinet.com.uy
} 
Dans le deuxième essai, un supplément de blé a été comparé à un supplément de maïs $(3,8 \mathrm{~kg})$. Pour chaque animal et pour les deux essais, la dynamique journalière du $\mathrm{pH}$ ruminal et la dégradation in sacco de la matière sèche (MS) et des fractions fibreuses des fourrages ont été déterminées. De plus, la digestibilité in vitro (IVTD) de différents aliments a été évaluée en utilisant le contenu ruminal des animaux du deuxième essai. La supplémentation a entraîné une diminution du $\mathrm{pH}$ ruminal ("fourrage" : 6,54 vs. " grain " :6,24, $P<0,001$ ) et de la vitesse de dégradation de la MS, laquelle a été plus faible lorsque les vaches ont été supplémentées $(P=0,048)$. La nature de la céréale (blé vs. maïs) n'a eu d'effet ni sur le $\mathrm{pH}$ ni sur le $\mathrm{NH}_{3}-\mathrm{N}$ ruminal et la dégradation in sacco de la matière sèche et des fractions fibreuses du fourrage incubé. Cependant, la IVTD était supérieure lorsque les vaches ont consommé du maïs, particulièrement pour les aliments les plus fibreux.

environnement ruminal / dégradabilité ruminale / prairies tempérées / blé / maïs

\section{INTRODUCTION}

Temperate pastures make up most of the Uruguayan bovine diet with concentrates, rarely exceeding one third of the whole diet. Ground grains and grain by-products are commonly used supplements, provided once or twice daily and completely consumed within a few minutes. However, both the quantity and the fermentation rate of the supplement can affect the rumen environment [11] and hence, the utilisation efficiency and degradability of the forage. Moreover, the nitrogen fractions of temperate pastures are rapidly and extensively degraded in the rumen, producing $\mathrm{NH}_{3}-\mathrm{N}[14,16]$. Grains, containing easily fermentable carbohydrates are suggested to improve the microbial incorporation of the $\mathrm{NH}_{3}-\mathrm{N}$ produced from the pasture [10] through optimised synchronisation. Nevertheless, grain sources show differences in ruminal fermentation rates, with corn and sorghum having a slow fermentation rate, whereas wheat and barley are rapidly and completely fermented in the rumen $[6,8]$.

However, most trials have been performed under confinement conditions, with high concentrate/forage diets, whereas less information is available about the effect of grain supplementation on the rumen environment under grazing situations. Hence, the aim of this work was to evaluate the effect of a pulse grain supplementation to grazing cows, on ruminal $\mathrm{pH}$ and $\mathrm{NH}_{3}-\mathrm{N}$ concentration and on pasture degradability.
In a second experiment, wheat and barley supplementation was compared.

\section{MATERIALS AND METHODS}

\subsection{Experimental design}

Two experiments were conducted on the Experimental farm of the Veterinary Faculty of Uruguay, located in the San José Department, Uruguay ( $34^{\circ}$ latitude south and $55^{\circ}$ longitude west). Four dry rumen cannulated Holstein cows, on average weighing $600 \mathrm{~kg} \mathrm{BW}$, were used. The cows were grazing a mixed grass/legume pasture (Trifolium repens, Festuca arundinacea, Lolium multiflorum, Lotus corniculatus), in the vegetative stage during the spring. The experiments consisted of a 7 day adaptation period, followed by 7 days of an experimental period. Two cows per treatment were used in each period according to a cross-over design.

In a first exploratory assay (Experiment 1) the treatments were the following: pasture grazed as sole feed (treatment: 'pasture') and pasture grazed and supplemented with a mixture of corn and barley $(50 / 50, \mathrm{w} / \mathrm{w})$ (treatment: 'grain'). The chemical composition of the pasture grazed and of the grains used is shown in Table I. The daily amount of supplement assigned was $1 \%$ of the BW (6 kg on average). It was provided ground, individually and in two equal meals (08:00 and 
Table I. Dry matter availability and chemical composition of the pastures and feedstuffs used during the experiments (values expressed as $\mathrm{g} \cdot \mathrm{kg}^{-1} \mathrm{DM}$ ).

\begin{tabular}{lcccccc}
\hline & availability $^{1}$ & DM & OM & CP & NDF & ADF \\
\hline pasture Experiment $1^{*}$ & 2300 & 181 & 915 & 177 & 421 & 203 \\
pasture Experiment 2 & 3500 & 206 & 905 & 180 & 478 & 227 \\
barley grain & - & 900 & 974 & 113 & 190 & 70.0 \\
corn grain $^{\dagger}$ & - & 876 & 983 & 86.3 & 88.0 & 18.4 \\
wheat grain $^{\dagger}$ & - & 876 & 978 & 130 & 126 & 32.4 \\
corn silage $^{2 \dagger}$ & - & 259 & 951 & 62.4 & 611 & 292 \\
grass hay $^{\dagger}$ & - & 895 & 891 & 101 & 813 & 501 \\
grass silage $^{\dagger}$ & - & 634 & 897 & 98.0 & 661 & 482 \\
pasture $^{\mathbf{}}$ & - & 194 & 885 & 231 & 404 & 147 \\
pasture $^{\dagger}$ & - & 190 & 916 & 163 & 436 & 351 \\
pasture $3^{\dagger}$ & - & 216 & 898 & 125 & 446 & 312 \\
\hline
\end{tabular}

${ }^{1}$ : $\mathrm{kg} \mathrm{DM} \cdot \mathrm{ha}^{-1}{ }^{2}$ : whole plant; ${ }^{*}$ : incubated in nylon bags (Exp. 1); ${ }^{\mathbf{4}}$ : incubated in nylon bags (Exp. 2); ${ }^{\dagger}$ : used for in vitro ruminal digestibility (IVTD); DM: dry matter $\left(\mathrm{g} \cdot \mathrm{kg}^{-1}\right)$; OM: organic matter; CP: crude protein; NDF: neutral detergent fibre; ADF: acid detergent fibre; pasture 1,2 and 3: mixtures of grasses and legumes dried at $60{ }^{\circ} \mathrm{C}$.

18:00 h). For each animal, period and treatment, the evolution of ruminal $\mathrm{pH}$ during $24 \mathrm{~h}$ and the degradability of dry matter (DM), neutral detergent fibre (NDF), acid detergent fibre (ADF) and hemicelluloses (HEM) of the grazed pasture were studied.

Based on the results of this preliminary exploration, a comparison of the two grains was made (Experiment 2). During this experiment wheat (treatment: 'wheat') or corn (treatment: 'corn') was supplemented to grazing animals. The total amount of grain represented $33 \%$ of the daily amount of DM ingested. It was provided ground, individually in two equal meals (10:00 and 22:00 h). From 08:00 to 12:00 and from 20:00 to $24: 00 \mathrm{~h}$, cows were confined and not allowed to graze. In order to adjust the quantity of grain to total DM ingestion, individual intake of pasture was estimated as follows: before the adaptation period, cows were individually tied to a stake. For each cow the grazing area and the availability of pasture before and after grazing was measured daily for 10 days. The measurement of pasture availability (before and after grazing) was performed by cutting three strips $(0.5 \times 0.2 \mathrm{~m})$ and collecting total herbage mass using manual scissors. Pasture samples were weighed and dried at $60{ }^{\circ} \mathrm{C}$ for $48 \mathrm{~h}$ for DM determination. During this period of intake determination, each cow was supplemented with $3 \mathrm{~kg}$ of grain. During this period, the average intake of pasture was $8.5 \mathrm{~kg}$ of DM. The individually distributed quantity of grain for the experimental period was adjusted according to the estimation of total DM intake (pasture + grain) of each animal (3.8 $\mathrm{kg}$ of DM on average). For each animal, period and treatment, the analyses performed were the following: the evolution of ruminal $\mathrm{pH}$ and $\mathrm{NH}_{3}-\mathrm{N}$ concentration during $24 \mathrm{~h}$, the degradability of pasture DM, NDF, ADF and HEM and the in vitro ruminal digestibility (IVTD) of 8 feedstuffs (corn grain, wheat grain, corn silage, grass hay, grass silage, pasture 1, pasture 2 and pasture 3 ). The characteristics of the pasture and feedstuffs used during the experimental period are presented in Table I. 


\subsection{Rumen $\mathrm{pH}$ and $\mathrm{NH}_{3}-\mathrm{N}$ concentration}

Rumen $\mathrm{pH}$ and $\mathrm{NH}_{3}-\mathrm{N}$ concentration were recorded every $60 \mathrm{~min}$ for $24 \mathrm{~h}$. Rumen liquor was taken through permanent tubes inserted in the rumen by the cannula and $\mathrm{pH}$ was measured immediately after sampling. For $\mathrm{NH}_{3}-\mathrm{N}$ determination, a sample of $10 \mathrm{~mL}$ was conserved with $10 \mathrm{~mL}$ of $200 \mathrm{~g} \cdot \mathrm{kg}^{-1} \mathrm{NaCl}$ and frozen. After thawing, $\mathrm{NH}_{3}-\mathrm{N}$ was determined by direct distillation in Kjeldhal equipment. The results were expressed as $\mathrm{mg}$ of $\mathrm{NH}_{3}$ $\mathrm{N} \cdot 100 \mathrm{~mL}^{-1}$ of ruminal liquor. The ingestive activity prior to sampling was registered (grazing, no-grazing) for each animal.

\subsection{Rumen degradability}

Degradability trials were performed by the in situ method. Forages were dried in an air forced oven at $60{ }^{\circ} \mathrm{C}$ to constant weight and ground to pass a 2-mm screen. Samples $(5 \mathrm{~g})$ were introduced into nylon bags $(10 \times 20 \mathrm{~cm}, 52 \mu \mathrm{m}$ pore size, ANKOM Technology Corp. Fairport, NY, USA). Forages were incubated for 2, 4, 8 , 12, 24, 48 and $72 \mathrm{~h}$ (Experiment 1) and for $3,6,12,24,48,72$ and $96 \mathrm{~h}$ (Experiment 2), performing two series per incubation time, introducing the bags $2 \mathrm{~h}$ before grain supplementation. After being removed from the rumen, the bags were washed with tap water and frozen. Three additional bags were stored after washing without rumen incubation and were considered the $0 \mathrm{~h}$ incubation. After thawing, the bags were manually washed with tap water $(10 \mathrm{~min})$, dried at $80{ }^{\circ} \mathrm{C}$ for $48 \mathrm{~h}$ and analysed for NDF and ADF. Disappearance of DM, NDF, ADF and HEM calculated from bag residues were fitted by non-linear regression for each sample, cow, period and treatment to the exponential model proposed by Ørskov and Mc-
Donald [9]:

$$
d=a+b\left(1-e^{-k d t}\right)
$$

where $d(\%)$ is the disappearance of forage at time $t, a(\%)$ is the soluble fraction, $b$ $(\%)$ is the non-soluble but degradable fraction and $k_{d}\left(\% \cdot \mathrm{h}^{-1}\right)$ is the fractional degradation rate of fraction $b$. The undegradable fraction $(u)(\%)$ was calculated as $100-$ $(a+b)$. When NDF, ADF and HEM fractions were fitted, $a$ was assumed 0 , since $0 \mathrm{~h}$ incubations revealed no disappearance of these fractions. Effective degradability was calculated as

$$
\mathrm{ED}=a+(b \times k d /(k d+k p))
$$

using constant rumen particulate outflow rates $(\mathrm{kp})$ of $6 \% \cdot \mathrm{h}^{-1}(\mathrm{ED} 06)$ and $3 \% \cdot \mathrm{h}^{-1}$ (ED03).

\subsection{In vitro rumen digestibility}

In vitro rumen digestibility (IVTD) of the feedstuffs described in Table I was determined in a DAISY equipment (DAISY ${ }^{\circledR}$ in vitro rumen fermenter, Ankom Technology Corp. Fairport, NY, USA) using rumen liquor of both maize and barley supplemented animals during the experimental period. Five hundred $\mathrm{mL}$ of rumen liquid was sampled 2 hours after grain supplementation and used immediately. The samples of feedstuffs were ground to pass a 2-mm screen and incubated in porous bags during $48 \mathrm{~h}$ (2 replicates). After incubation, the bags were washed for $1 \mathrm{~h}$ at $100{ }^{\circ} \mathrm{C}$ in a neutral detergent solution and dried in an air forced oven at $105^{\circ} \mathrm{C}$ to constant weight [1]. The IVTD was calculated as the percentage of material disappearing after incubation and washing procedures.

\subsection{Chemical analysis}

The samples were analysed for dry matter (DM, $105{ }^{\circ} \mathrm{C}$ until constant weight, 
unless stated differently), organic matter (OM, $550^{\circ} \mathrm{C}$ for 3 hours) and crude protein (CP, Kjeldhal analysis) contents according to AOAC [2]; neutral detergent fibre (NDF) and acid detergent fibre (ADF) according to Robertson and Van Soest [15]. Hemicellulose (HEM) was calculated as NDFADF. For chemical analyses, the samples were ground to pass a 1-mm screen.

\subsection{Statistical analysis}

Data were analysed using the Statistical Analysis System (SAS). $\mathrm{pH}$ and $\mathrm{NH}_{3}-\mathrm{N}$ concentrations were analysed as repeated measures using the mixed model (PROC MIXED). The model included the fixed effect of treatment, the interaction treatment per hour, and the random effects of cow and period. The values of $a, b, u, k d$, ED and IVTD were studied by analysis of variance (ANOVA). The model included the effects of treatment, period and cow. Rumen degradation parameters in experiment 2 and IVTD results were analysed for the feedstuffs altogether and for each one separately. Linear correlation analysis between $\mathrm{pH}$ and $\mathrm{NH}_{3}-\mathrm{N}$ concentration was made. The differences were considered significant at $P<0.05$.

\section{RESULTS}

\subsection{Experiment 1 (exploratory assay)}

Mean rumen $\mathrm{pH}$ and its daily dynamics in cows grazing pasture as sole feed or supplemented with grain are presented in Table II and Figure 1. Mean pH values for 'pasture' and 'grain' treatments were different $(6.54$ vs. $6.24, P<0.001)$. The minimum mean value was observed $4 \mathrm{~h}$ post-supplementation (5.86, Fig. 1) for the 'grain' treatment, and averages for this treatment were below six, 1,4 and $5 \mathrm{~h}$ postsupplementation.
Table II also presents degradability parameters of DM, NDF, ADF and HEM of the forage incubated in the rumen of cows under 'pasture' and 'grain' treatments. Supplementation only affected the fractional DM degradation rate $(k d)$ of the forage, which was lower when cows consumed grain and pasture than when they consumed pasture as the sole feed $(0.103$ vs. $0.074 ; P=0.048$ ).

\subsection{Experiment 2 (comparison of two grains)}

Comparisons of rumen $\mathrm{pH}$ and $\mathrm{NH}_{3}$ $\mathrm{N}$ in cows grazing pasture and supplemented with wheat or corn are presented in Table III, but no differences were observed. Moreover, rumen $\mathrm{pH}$ and $\mathrm{NH}_{3}-$ $\mathrm{N}$ concentration dynamics were similar, as evidenced by the absence of significant interactions between the treatment and time after supplementation. However, both parameters significantly differed with time after supplementation $(P<0.001)$. Figure 2A, shows considerable variations in rumen $\mathrm{pH}$. Minimum mean $\mathrm{pH}$ values were observed 8 to $11 \mathrm{~h}$ after the morning and 8 to $9 \mathrm{~h}$ after the evening supplementation ('wheat': 5.67, 'corn': 5.66 and 'wheat': 5.60, 'corn': 5.71, respectively). Maximum $\mathrm{NH}_{3}-\mathrm{N}$ concentrations were observed 8 hours after the morning supplementation ('wheat': 27.2 and 'corn': $30.5 \mathrm{mg} \cdot 100 \mathrm{~mL}^{-1}$; Fig. 2B). Maximum $\mathrm{pH}$ coincided with minimum $\mathrm{NH}_{3}-\mathrm{N}$ concentration. In fact, there was a low, but significant negative correlation between these two parameters when all measurements were considered $(\mathrm{r}=-0.39 ; P<0.001, \mathrm{n}=$ 185).

The supplemented grain source did not affect DM and fibre degradation characteristics of the forage studied (Tab. III).

The in vitro rumen digestibility (IVTD) of feedstuffs incubated in the rumen liquor of cows supplemented with wheat and corn 
Table II. Rumen $\mathrm{pH}(\mathrm{n}=96)$ and pasture nylon bag degradation characteristics $(\mathrm{n}=4)$ of pasture grazing (sole feed) or pasture grazing and grain supplemented cows (Exp. 1).

\begin{tabular}{|c|c|c|c|c|c|c|c|}
\hline & & \multicolumn{2}{|c|}{ treatment } & \multirow[b]{2}{*}{ SEM } & \multicolumn{3}{|c|}{$P$} \\
\hline & & pasture & grain & & $\mathrm{t}$ & $\mathrm{h}$ & $\mathrm{t} \times \mathrm{h}$ \\
\hline $\mathrm{pH}$ & & 6.54 & 6.24 & 0.026 & $<0.001$ & 0.089 & 0.952 \\
\hline \multicolumn{8}{|c|}{ Degradation characteristics } \\
\hline \multirow{6}{*}{ DM } & $a$ & 35.9 & 35.5 & 0.37 & 0.556 & & \\
\hline & $b$ & 53.2 & 54.1 & 0.97 & 0.576 & & \\
\hline & $u$ & 11.0 & 10.4 & 0.66 & 0.616 & & \\
\hline & $k_{d}$ & 0.103 & 0.074 & 0.005 & 0.048 & & \\
\hline & ED06 & 56.1 & 49.0 & 1.34 & 0.065 & & \\
\hline & ED03 & 68.8 & 63.4 & 1.07 & 0.068 & & \\
\hline \multirow{4}{*}{ NDF } & $b$ & 81.6 & 83.2 & 1.57 & 0.564 & & \\
\hline & $k_{d}$ & 0.081 & 0.063 & 0.005 & 0.144 & & \\
\hline & ED06 & 46.9 & 42.2 & 1.32 & 0.126 & & \\
\hline & ED03 & 59.6 & 55.8 & 0.99 & 0.116 & & \\
\hline \multirow{4}{*}{$\mathrm{ADF}$} & $b$ & 78.3 & 82.7 & 1.55 & 0.184 & & \\
\hline & $k_{d}$ & 0.064 & 0.048 & 0.004 & 0.118 & & \\
\hline & ED06 & 40.4 & 36.3 & 1.39 & 0.174 & & \\
\hline & ED03 & 53.3 & 50.3 & 1.22 & 0.224 & & \\
\hline \multirow{4}{*}{ HEM } & $b$ & 84.8 & 85.4 & 1.04 & 0.706 & & \\
\hline & $k_{d}$ & 0.096 & 0.081 & 0.011 & 0.425 & & \\
\hline & ED06 & 51.8 & 48.3 & 2.34 & 0.403 & & \\
\hline & ED03 & 64.3 & 61.6 & 1.67 & 0.381 & & \\
\hline
\end{tabular}

SEM: standard error of the mean; t: treatment effect; $h$ : hour effect; $\mathrm{t} \times \mathrm{h}$ : interaction between treatment and hour; DM: dry matter; NDF: neutral detergent fibre; ADF: acid detergent fibre; HEM: hemicelluloses; $a$ : soluble fraction; $b$ : non-soluble degradable fraction; $u$ : undegradable fraction; $k_{d}$ : fractional degradation rate of fraction $b$; ED03 and ED06: effective degradability using $k_{p}$ of 0.03 and $0.06 \cdot \mathrm{h}^{-1}$, respectively.

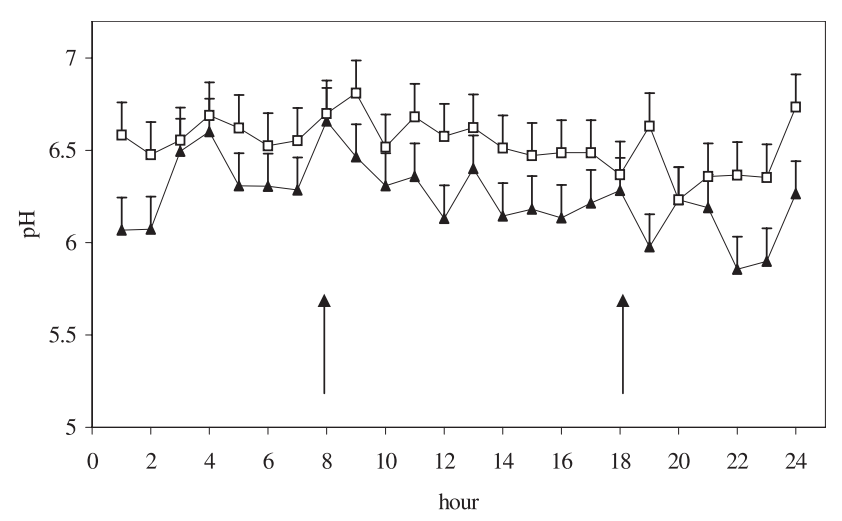

Figure 1. Diurnal rumen $\mathrm{pH}$ of cows grazing pasture as sole feed (open squares) and supplemented with grains (closed triangles) (means $\pm S E ; n=4$ ). Arrows indicate the moment of supplementation. 
Table III. Rumen $\mathrm{pH}, \mathrm{NH}_{3}-\mathrm{N}$ concentration $\left(\mathrm{mg} \cdot 100 \mathrm{~mL}^{-1}\right)(\mathrm{n}=96)$ and pasture nylon bag degradation characteristics $(n=4)$ of pasture grazing cows supplemented with wheat or corn (Exp. 2).

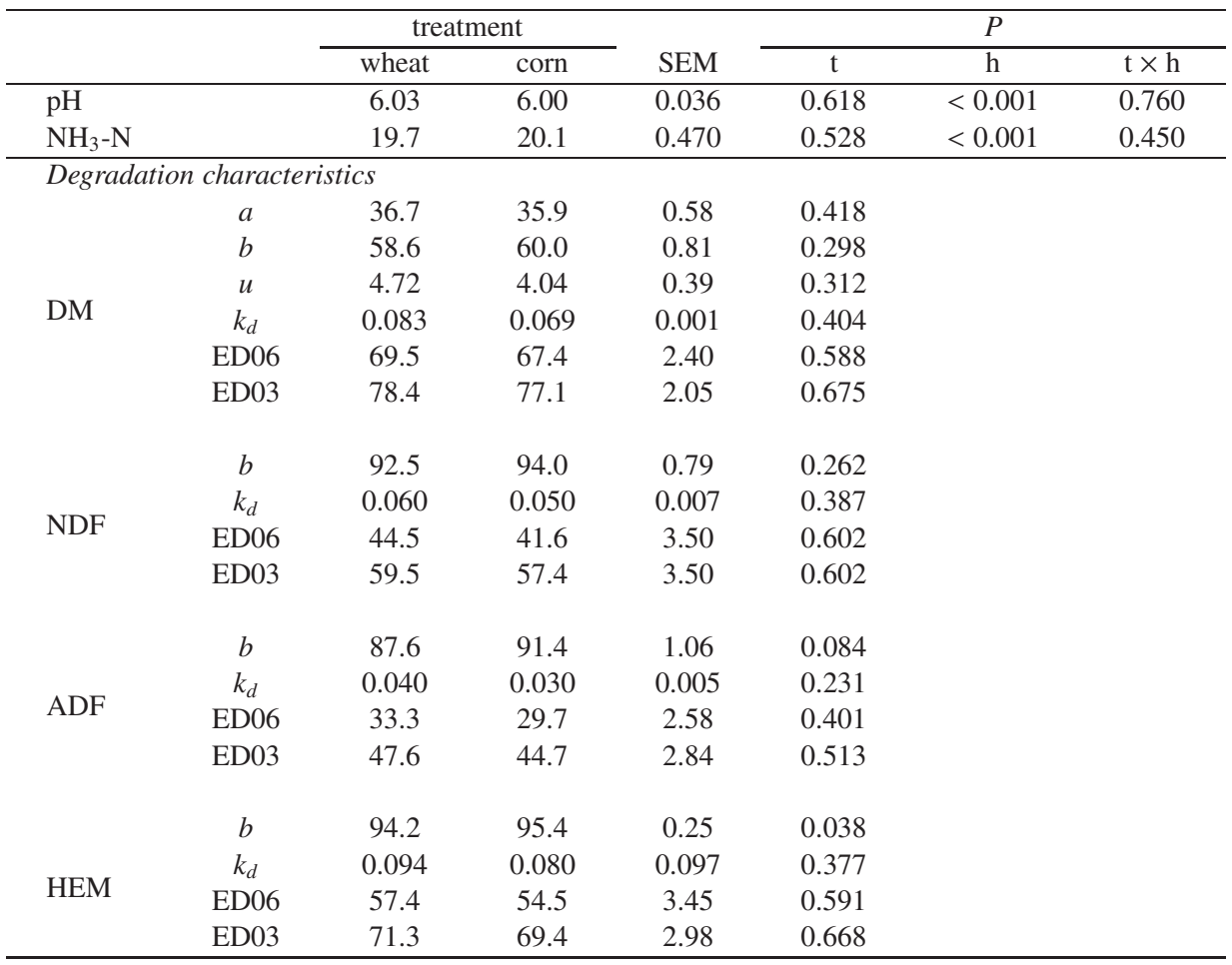

SEM: standard error of the mean; $\mathrm{t}$ : treatment effect; $\mathrm{h}$ : hour effect; $\mathrm{t} \times \mathrm{h}$ : interaction between treatment and hour; DM: dry matter; NDF: neutral detergent fibre; ADF: acid detergent fibre; HEM: hemicelluloses; $a$ : soluble fraction; $b$ : non-soluble degradable fraction; $u$ : undegradable fraction; $k_{d}$ : fractional degradation rate of fraction $b$; ED03 and ED06: effective degradability using $k_{p}$ of 0.03 and $0.06 \cdot \mathrm{h}^{-1}$, respectively.

is presented in Table IV. Mean IVTD for all feedstuffs studied was higher when cows consumed corn than wheat, but not always significantly different and of the same magnitude. The greatest differences were for grass hay and grass silage.

\section{DISCUSSION}

Rumen $\mathrm{pH}$ of animals grazing pasture as sole feed was always near the optimum for cellulolytic activity $(6.7 \pm 0.5$ according to Van Soest [17]) and was higher than values observed by other authors in similar conditions $[5,13]$. Supplementation led to significant lower $\mathrm{pH}$ values (Tab. II). Grain supplementation reduced fractional degradation rate $(k d)$ (Tab. II) which may be indicative of a lower cellulolytic activity. Nevertheless, no changes were observed on the degradation of any fibre compound. These results are different from those reported by Berzaghi et al. [3], who observed an important diminution in NDF digestion of the forage when lactating dairy cows were supplemented with a similar quantity of corn $(6.4 \mathrm{~kg}, 1.16 \%$ of the BW, $30 \%$ of the whole diet).

The average rumen $\mathrm{pH}$ of cows supplemented either with wheat or corn (Tab. III) 

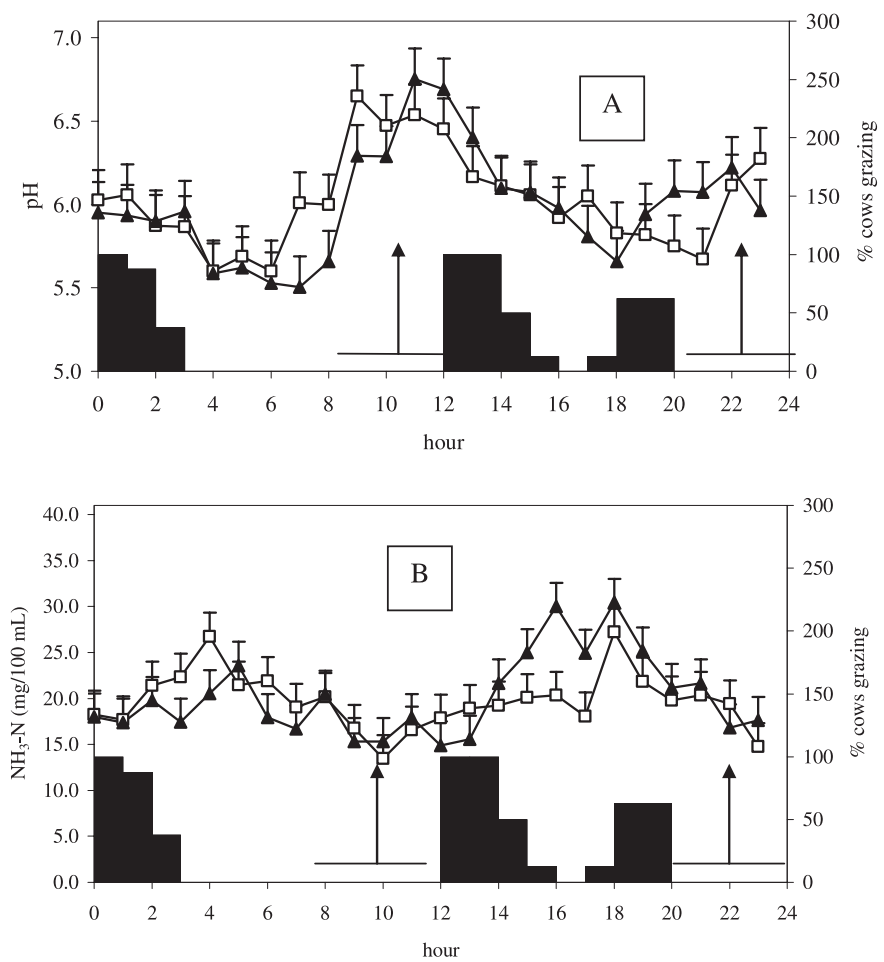

Figure 2. Diurnal rumen $\mathrm{pH}(\mathrm{A})$ and $\mathrm{NH}_{3}-\mathrm{N}$ (B) of grazing cows supplemented according to the grain with wheat (open squares) or corn (full triangles) (mean $\pm S E ; n=4)$. Black areas indicate the proportion of cows grazing after the confinement period. Arrows indicate the moment of supplementation; lines under arrows indicate confinement periods.

was around 6, and no differences were observed among treatments. Similarly, García et al. [5], studying rumen $\mathrm{pH}$ of dairy cows grazing temperate pastures did not find differences when supplementing barley or corn. Nevertheless, Figure 2A, revealed major daily fluctuations in rumen $\mathrm{pH}$. This was supposedly due to long periods of confinement during this experiment $\left(8 \mathrm{~h} \cdot \mathrm{day}^{-1}\right)$, leading to high rates of pasture ingestion during the grazing periods. Minimum $\mathrm{pH}$ was not registered immediately after supplementation but after a few hours of grazing. This was in agreement with the results of Rearte and Santini [13], under similar conditions.

$\mathrm{NH}_{3}-\mathrm{N}$ concentrations were similarly high for wheat and corn supple- mented cows (Tab. III) and similar to those reported by Berzaghi et al. [3] for cows grazing temperate pastures (22.4 mg.100 mL $\mathrm{m}^{-1}$ ). According to Jouany et al. [7], these concentrations guarantee $\mathrm{N}$ supply for optimal microbial growth.

In this work, a negative relationship between $\mathrm{pH}$ and $\mathrm{NH}_{3}-\mathrm{N}$ concentration was observed. Similar results were reported by Dalley et al. [4] measuring $\mathrm{pH}$ and $\mathrm{NH}_{3}$ $\mathrm{N}$ in animals grazing high quality pastures and supplemented with wheat and barley. As expected, maximum $\mathrm{NH}_{3}-\mathrm{N}$ concentrations were observed during grazing periods, which obviously is related to the ingestion of highly degradable grass crude protein, as observed in these types of pastures by Repetto et al. [14]. 
Table IV. In vitro $(48 \mathrm{~h})$ rumen digestibility (IVTD, \%) of feedstuffs incubated in the rumen liquid of cows grazing pasture and supplemented with wheat or corn (each feedstuff $\mathrm{n}=4)$.

\begin{tabular}{lcccc}
\hline & wheat & corn & SEM & $P$ \\
\hline corn grain & 89.2 & 91.6 & 0.57 & 0.011 \\
wheat grain & 90.4 & 91.7 & 0.44 & 0.063 \\
corn silage & 60.3 & 62.7 & 1.03 & 0.124 \\
grass hay & 40.9 & 45.2 & 0.62 & 0.045 \\
grass silage & 49.7 & 54.0 & 0.68 & $<0.001$ \\
pasture 1 & 86.9 & 88.2 & 0.65 & 0.194 \\
pasture 2 & 74.0 & 76.0 & 0.74 & 0.025 \\
pasture 3 & 78.9 & 79.9 & 1.09 & 0.520 \\
& & & & \\
average $(\mathrm{n}=32)$ & 71.4 & 73.6 & 0.28 & $<0.001$ \\
\hline
\end{tabular}

Wheat: pasture supplemented with wheat; corn: pasture supplemented with corn; SEM: standard error of the mean; average: mean IVTD value for all the feeds.

The grain used for supplementation had no effect on DM nor fibre degradation (Tab. III). Poore et al. [12] using diets with $30 \%$ of starch, observed higher rumen cellulose digestibility when concentrates contained slowly degradable starch, although global fibre digestibility was similar. Philippeau et al. [11] observed differences in DM degradation when corn or wheat were used, but in that work supplementation levels were higher $(67-75 \%$ of DM ingested).

Rumen liquor obtained from corn supplemented cows generally increased IVTD, with the largest differences observed for more fibrous feedstuffs (grass hay and silage).

According to these results, no differences would be expected on microbial $\mathrm{NH}_{3}-\mathrm{N}$ utilisation efficiency and rumen forage degradation upon supplementation of either wheat or corn under Uruguayan grazing conditions. However, the lower IVTD observed when fibrous materials were incubated in wheat supplemented cows are indicative of changes in microbial populations. These changes can have negative consequences in productive performances if the supplementation level rises.

\section{CONCLUSION}

It is concluded that, under the present experimental conditions the addition of grain led to lower ruminal $\mathrm{pH}$. However, rumen degradation of the grazed forage was not affected to a major extent irrespective of the nature of the grain supplement. Nevertheless, higher IVTD, particularly of fibrous material in incubation with rumen liquor of corn supplemented cows may be indicative of some pressure on cellulolytic micro-organisms when supplementing wheat instead of corn.

\section{ACKNOWLEDGEMENTS}

The authors want to thank Ana Curbelo, Nicolás Errandonea, Mauricio Alonso, Claudio Soto, Mariano Mota, Pablo Marinho, Laura Vega for sampling contribution and Alejandro Bielli for English revision. Comisión de Investigación y Desarrollo Científico (CIDEC, Facultad de Veterinaria, UdelaR) supported this study.

\section{REFERENCES}

[1] Ankom Website, In Vitro True Digestibility using the DAISY II Incubator ANKOM Technology -03/05, [Online] Available: http://www.ankom.com/09_procedures/ Daisy\%20method.pdf, 2006.

[2] AOAC Official methods of analysis, 14th ed., Association of Official Analytical Chemists, Washington, DC, 1984.

[3] Berzaghi P., Herbein J.H., Polan C.E., Intake, site and extent of nutrient digestion of lactating cows grazing pasture, J. Dairy Sci. 79 (1996) 1581-1589.

[4] Dalley D.E., Roche J.R., Grainger C., Effect of grain or buffer supplementation on milk solids yield and rumen fermentation patterns 
of cows grazing highly digestible herbage in spring, Proc. N.Z. Soc. Anim. Prod. 61 (2001) 224-228.

[5] García S.C., Santini F.J., Elizalde J.C., Sites of digestion and bacterial protein synthesis in dairy heifers fed fresh oats with or without corn or barley grain, J. Dairy Sci. 83 (2000) 746-755.

[6] Huntington G.B., Starch utilization by ruminants: from basics to the bunk, J. Anim. Sci. 75 (1997) 852-867.

[7] Jouany J.P., Broudiscou L., Prins R.A., Komisarczuk-Bony S., Métabolisme et nutrition de la population microbienne du rumen, in: Jarrige R., Ruckebusch Y., Demarquilly C., Farce M.H., Journet M. (Eds.), Nutrition des ruminants domestiques. Ingestion et digestion, INRA, Paris, 1995, pp. 349-381.

[8] Offner A., Bach A., Sauvant D., Quantitative review of in situ starch degradation in the rumen, Anim. Feed Sci. Tech. 106 (2003) 8193.

[9] Ørskov E.R., McDonald I., The estimation of protein degradability in the rumen from incubation measurements weighted according to a rate of passage, J. Agr. Sci. Camb. 92 (1979) 499-503.

[10] Owens F.N., Secrist D.S., Hill W.J., Gill D.R., The effect of grain source and grain processing on performance of feedlot cattle: a review, J. Anim. Sci. 75 (1997) 868-879.

[11] Philippeau C., Martin C., Michalet-Doreau B., Influence of grain source on ruminal characteristics and rate, site and extent of digestion in beef steers, J. Anim. Sci. 77 (1999) 1587-1596.

[12] Poore M.H., Moore J.A., Eck T.P., Swingle R.S., Theurer C.V., Effect of fiber source and ruminal starch degradability on site and extent of digestion in dairy cows, J. Dairy Sci. 76 (1993) 2244-2253.

[13] Rearte D.H., Santini F.J., Digestión ruminal y producción en animales en pastoreo, Rev. Agr. Prod. Anim. 9 (1989) 93-105.

[14] Repetto J.L., Cajarville C., D’Alessandro J., Curbelo A., Soto C., Garin D., Effect of wilting and ensiling on ruminal degradability of temperate grass and legume mixtures, Anim. Res. 54 (2005) 73-80.

[15] Robertson J.B., Van Soest P.J., The detergent system of analysis and its application to human foods, in: James W.P.T., Theander O. (Eds.), The analysis of dietary fibre in food, Marcel Dekker, New York, 1981, pp. 123158.

[16] Sauvant D., Grenet E., Doreau M., Dégradation chimique des aliments dans le réticulo-rumen : cinétique et importance, in: Jarrige R., Ruckebusch Y., Demarquilly C., Farce M.H., Journet M. (Eds.), Nutrition des ruminants domestiques. Ingestion et digestion, INRA, Paris, 1995, pp. 383-406.

[17] Van Soest P.J., Nutritional ecology of the ruminant, Cornell University Press, Ithaca, NY, 1994. 